\title{
Erratum: Impact of stem cells in craniofacial regenerative medicine
}

\section{Pedro A. Sanchez-Lara *}

Departments of Pediatrics and Pathology and Laboratory Medicine, Children's Hospital Los Angeles, University of Southern California, Los Angeles, CA, USA

*Correspondence: pedro.sanchez@usc.edu

Edited by:

Anis Feki, Hopitaux fribourgeois, Switzerland

Reviewed by:

Gianpaolo Papaccio, Second University of Naples, Italy

Petros Papagerakis, University of Michigan, USA

Keywords: stem cell, craniofacial, regeneration

\section{A commentary on}

Impact of stem cells in craniofacial regenerative medicine

by Sanchez-Lara, P. A., Zhao, H., Bajpai, R., Abdelhamid, A. I., and Warburton, D. (2012). Front. Physiol. 3:188. doi: 10.3389/ fphys.2012.00188

We would like to apply a correction to the authorship and acknowledgments section of this manuscript.

\section{AUTHORS}

Pedro A. Sanchez-Lara ${ }^{1,2}$ and David Warburton ${ }^{1,2}$

${ }^{1}$ Departments of Pediatrics and Pathology and Laboratory Medicine, Keck School of Medicine, Children's Hospital Los Angeles, University of Southern California, Los Angeles, CA, USA
${ }^{2}$ Developmental Biology and Regenerative Medicine Program, Saban Research Institute, Children's Hospital Los Angeles, Los Angeles, CA, USA

\section{ACKNOWLEDGMENTS}

We wish to thank Drs. $\mathrm{Hu}$ Zhao and Ruchi Bajpai for their helpful suggestions and contributions to this manuscript and figures and Dr. Alaa I. Abdelhamid for his support and effort in facilitating this publication. This work was made possible by institutional support from the Children's Hospital Los Angeles, Saban Research Institute and the Keck School of Medicine at the University of Southern California. Pedro A. Sanchez-Lara was supported by the Harold Amos Faculty Development Program through the Robert Wood Johnson Foundation.

Alaa Abdel-hamid is supported by grants from the Kingdom of Saudi
Arabia and has applied for additional research and training support from KSA together with David Warburton. David Warburton directs the California Institute for Regenerative Medicine Training Grant and Shared Laboratory at Children's Hospital Los Angeles.

Received: 23 July 2013; accepted: 29 July 2013; published online: 29 August 2013.

Citation: Sanchez-Lara PA (2013) Erratum: Impact of stem cells in craniofacial regenerative medicine. Front. Physiol. 4:219. doi: 10.3389/fphys.2013.00219

This article was submitted to Craniofacial Biology, a section of the journal Frontiers in Physiology.

Copyright (c) 2013 Sanchez-Lara. This is an openaccess article distributed under the terms of the Creative Commons Attribution License (CC BY). The use, distribution or reproduction in other forums is permitted, provided the original author(s) or licensor are credited and that the original publication in this journal is cited, in accordance with accepted academic practice. No use, distribution or reproduction is permitted which does not comply with these terms. 